\title{
Pelaksanaan Asesmen Kebutuhan Peserta Didik dalam Memberikan Layanan Bimbingan Klasikal di SMA Ambon
}

\author{
Sawal Mahaly \\ Universitas Pattimura Ambon
}

\begin{tabular}{l}
\hline Article Info \\
\hline Article history: \\
Received Jun $12^{\text {th }}, 2021$ \\
Revised Aug $20^{\text {th }}, 2021$ \\
Accepted Oct $30^{\text {th }}, 2021$ \\
\hline
\end{tabular}

Keyword:

Angket Kebutuhan Peserta Didik, Bimbingan Klasikal, Analisis Kebutuhan Peserta Didik

\begin{abstract}
Angket kebutuhan Peserta Didik (AKPD) merupakan sebuah angket yang berisi sejumlah soal berupa pernyataan terkait dengan masalahmasalah yang diasumsikan biasa terjadi pada peserta didik. Hasil pengolahan angket tersebut membnatu guru bimbingan dan konseling merancang program bimbingan konseling untuk mambantu peserta didik mengatasi permasalahan yang dialaminya. Tujuan dari penelitian ini adalah untuk membantu guru bimbingan dan konseling dalam melaksanakan program bimbingan konsleing bagi peserta didik. Jenis penelitian ini merupakan penelitian deskriptif. Metode penentuan sampel menggunakan sampling jenuh. Berdasarkan hasil penelitian Analisis Kebutuhan Peserta Didik yang paling dibutuhkan dalam pemberian layanan adalah materi tentang mengenal lingkungan sekolah baru, memperoleh bantuan pendidikan (beasiswa), memahami perubahan dan permasalahan masa remaja, dan jarang bermain/berteman dengan lingkungan sekitar.
\end{abstract}

\section{Corresponding Author:}

Sawal Mahaly

Universitas Pattimura Ambon

Email: sawal.mahaly@fkip.unpatti.ac.id

\section{Pendahuluan}

Konteks bimbingan di sekolah dan madrasah Hamalik menyatakan bahwa bimbingan di sekolah merupakan aspek program pendidikan yang berkenaan dengan bantuan terhadap peserta didik agar menyesuaikan diri dengan situasi yang dihadapinya dan untuk merencanakan masa depannya sesuai dengan minat, kemampuan, dan kebutuhan sosialnya. Bimbingan merupakan bantuan yang diberikan kepada peserta didik untuk dapat mengenal dan memecahkan masalah yang dialaminya agar dapat menikmati hidup secara bahagia. Oleh sebab itu, apa pun pembicaraan tentang bimbingan termaksud konseling tidak boleh lepas dari hakikat pendidikan. Dengan demikian, dalam pelayanan konseling harus memuat aspek-aspek pendidikan seperti; 1) usaha sadar dari pembimbing atau konselor kepada peserta didik (konseli), 2) menyiapkan peserta didik, 3) untuk perannya dimasa yang akan datang yang diwujudkan melalui tujuan-tujuan bimbingan konseling (Tohirin, 2011)

Bimbingan dan konseling pada satuan pendidikan diselenggarakan untuk membantu peserta didik/konseli dalam mencapai tugas-tugas perkembangannya. Tugas perkembangan ini diantaranya meliputi: (1) Mencapai perkembangan diri sebagai remaja yang beriman dan bertakwa kepada Tuhan Yang Maha Esa; (2) Mengenal sistem etika dan nilai-nilai bagi pedoman hidup sebagai pribadi, anggota masyarakat, dan minat 
manusia; (3) Mengenal gambaran dan mengembangkan sikap tentang kehidupan mandiri secara emosional, sosial, dan ekonomi; (4) Mengembangkan pengetahuan dan keterampilan sesuai denga kebutuhannya untuk mengikuti dan melanjutkan pelajaran dan/atau mempersiapkan karier serta berperan dalam kehidupan masyarakat; (5) Memantapkan nilai dan cara bertingkah laku yang dapat diterima dalam kehidupan sosial yang lebih luas; (6) Mencapai pola hubungan yang baik dengan teman sebaya dalam peranannya sebagai pria atau wanita; (7) Mempersiapkan diri, menerima dan bersikap positif serta dinamis terhadap perubahan fisik dan psikis yang terjadi pada diri sendiri untuk kehidupan yang sehat; (8) Memiliki kemandirian perilaku ekonomis; (9) Mengenal kemampuan, bakat, minat, serta arah kecenderungan karier dan apresiasi seni; (10) Mencapai kematangan hubungan dengan teman sebaya; dan (11) Mencapai kematangan dalam kesiapan diri menikah dan hidup berkeluarga (Kementrian Pendidikan dan Kebudayaan, 2016)

Menurut Zamroni dan Raharjo Bimbingan dan konseling (BK) merupakan suatu layanan yang diberikan kepada peserta didik untuk mengembangkan potensinya secara optimal. Pelayanan tersebut membutuhkan kinerja guru BK/konselor yang memiliki kompetensi serta profesional guna layanan yang diberikan dapat mencapai sasaran yakni sesuai dengan kebutuhan siswa diberbagai bidang, baik di bidang pribadi, sosial, belajar, dan karir. Untuk mewujudkan tercapainya sasaran yang dimaksud, pelayanan BK harus dilaksanakan secara terencana dan sistematis. Setiap rencana dan langkah sistematis pelayanan yang dimaksud harus tersusun dalam program bimbingan dan konseling (Rahmad et al., 2019)

Layanan bimbingan dan konseling di sekolah diatur dalam Peraturan Menteri Pendidikan dan Kebudayaan nomor 111 tahun 2014 tentang Bimbingan dan Konseling pada Pendidikan Dasar dan Pendidikan Menengah beserta lampirannya. Pasal 12 ayat 2 dan 3 Permendikbud tersebut mengamanatkan pentingnya disusun panduan operasional yang merupakan aturan lebih rinci sebagai penjabaran dari Pedoman Bimbingan dan Konseling sebagaimana tertera pada lampiran Permendikbud tersebut. Salah satu panduan yang dimaksud adalah Panduan Bimbingan dan Konseling Sekolah Menengah Atas (SMA) (Kementrian Pendidikan dan Kebudayaan, 2016)

Menurut Sudibyo dalam bimbingan dan konseling konselor sekolah melakukan identifikasi kebutuhan (need assessment) pada peserta didik dan lingkungan sekolah sebelum melaksanakan layanan bimbingan dan konseling. untuk memperoleh informasi kebutuhan peserta didik dapat digunakan Inventoru Tugas Perkembanan (ITP), Alat Ungkap Masalah (AUM), Daftar Cek Masalah (DCM), Analisis Kebutuhan Peserta Didik (AKPD), Sosiometri atau Tes Minat Bakat dapat juga digunakan intrumen wawancara, angket atau observasi. Sedangkan kebutuhan lingkungan antara lain adanya dukungan orang tua, guru, kepala sekolah dan Stakeholder lainnya). Berdasarkan deskripsi kebutuhan tersebut selanjutnya dilakukan analisis dan direncanakan untuk perencanaan program bimbingan dan konseling (Permadin, 2021)

Penyelenggaraan layanan bimbingan dan konseling disekolah merupakan tugas pokok guru bimbingan konseling di sekolah. Dalam hal ini, guru bimbingan konseling harus mampu mengembangkan dan melaksanakannya sesuai dengan fungsi kontrolnya sebagai penanggungjawab layanan bimbingan dan konseling di sekolah, salah satu tugas yang perlu dikembangkannya yaitu guru bimbingan dan konseling dapat menggunakan berbagai aplikasi teknik no tes dalam bimbingan dan konseling salah satunya aplikasi daftar cek masalah (DCM) untuk memperoleh berbagai informasi kebutuhan yang diperlukan oleh peserta didik (Divinubun et al., 2021)

Tujuan umum bimbingan dan konseling menurut Zainal Aqib dilaksanakan dengan tujuan untuk memberikan pertolongan kepada individu. Agar tercapai tujuan tersebut, maka setiap individu yang mendapatkan layanan bimbingan hendaknya memperoleh kesempatan sebagai berikut (; 1) mengenal dan melaksanakan tujuan hidupnya serta merumuskan rencana hidupnya yang didasarkan atas tujuan itu, 2) mengenal dan memahami kebutuhan-kebutuhannya, 3) mengenal dan menanggulangi kesulitan-kesulitan yang dihadapinya, 4) mengenal dan memperkembangkan kemampuan-kemampuannya secara optimal, 5) mempergunakan kemampuannya untuk kepentingan pribadinya dan kepentingan umum dalam keiudpan bersama, 6) menyesuaikan diri dengan keadaan dan tuntutan dalam lingkungan, 7) memperkembangkan segala yang dimilikinya secara tepat dan teratur, sesuai dengan tugas perkembangannya sebagai batas optimal. Dengan demikian dapat artikan bahwa peran guru bimbingan dan konseling dibutuhkan di sekolah untuk membantu peserta didik memamahi kemampuan yang dimilikinya. Sedangkan tujuan bimbingan di sekolah dilihat dari segi siswa yang menerima bimbingan, maka rumusan tujuanya agar para siswa dengan kemampuan yang dimilikinya dapat; 1) mengatasi kesulitan dalam memahami dirinya, 2) memahami kesulitan dalam memahami lingkungannya yaitu lingkungan sekolah, keluarga dan masyarakat, 3) mengatasi kesulitan dalam mengidentifikasi dan memecahkan masalahnya, 4) mengatasi kesulitan dalam menyalurkan kemampuannya, minat, bakat, dalam bidang pendidikan dan pekerjaan, 5) memperoleh bantuan secara tepat dari pihak-pihak luar sekolah untuk mengatasi kesulitan-kesulitan yang tidak dapat dipecakan disekolah. Hal ini dapat dimaknai bahwa peran guru bimbingan dan konseling sangat penting untuk membantu mengatasi masalah yang dialami oleh peserta didik (Mahaly, 2021).

Guru bimbingan dan konseling atau konselor dapat menggunakan instrumen yang dikembangkan sendiri dengan langkah-langkah sebagaimana pengonstruksian instrument tes. Langkah-langkah pengembangan 
instrument tes meliputi: menetapkan tujuan pengungkapan data pribadi, menentukan aspek dan atau dimensi yang diukur, merumuskan definisi operasional, memilih cara pengukuran yang digunakan, instrumen dan lembar jawaban, merumuskan manual penggunaan instrumen, penyekoran atau pengolahan, serta interpretasinya. Adapun teknik asesmen non tes yang sering digunakan untuk keperluan bimbingan dan konseling antara lain: (a) observasi, (b) wawancara (c) angket, (d) sosiometri, (e) dokumentasi, (f) biografi ataupun autobiografi. Instrumen pengumpul data yang sering digunakan untuk mengenali masalah serta kebutuhan layanan bantuan antara lain: (a) daftar cek masalah (DCM), (b) alat ungkapmasalah (AUM), (c) inventori tugas perkembangan (ITP) serta Analisis Kebutuhan Peserta didik (AKPD) (Kementrian Pendidikan dan Kebudayaan, 2016).

Sedangkan pemanfaatan data hasil asesmen adalah data yang diperoleh melalui teknik tes dan nontes. Data hasil pemahaman terhadap peserta didik/konseli dapat digunakan untuk: 1) Membuat profil individual setiap peserta didik/konseli, berdasarkan data hasil asesmen maka setiap peserta didik/konseli dapat disusun profil yang menggambarkan tentang identitas diri peserta didik, karakteristik tugas perkembangan, klasifikasi kecerdasan, bakat, minat, motivasi belajar, kesiapan belajar, kemampuan hubungan sosial, kematangan emosi, prestasi akademik dan non akademik yang dimiliki, latar belakang keluarga-sekolah-masyarakat dan lain-lain, serta gambaran tentang kekuatan dan kelemahan setiap peserta didik/konseli. 2) Membuat profil kelas. Berdasarkan data individual peserta didik/konseli tersebut, maka dikembangkan profil kelas, sehingga tiap kelas memiliki profilnya sendiri-sendiri. Profil sebaiknya dituangkan ke dalam bentuk matrik, misalnya dalam format landscape excel, atau dalam bentuk grafik sehingga semua data dapat dimasukkan. Dengan profil kelas ini, dapat diketahui kedudukan peserta didik/konseli dalam kelasnya. Profil akan menggambarkan variasi kebutuhan layanan bimbingan dan konseling yang meliputi: bimbingan dan konseling pribadi, sosial, belajar, dan karir. 3) Menyusun rancangan program layanan bimbingan dan konseling. Berdasarkan profil individual dan kelas disusun rancangan program layanan bimbingan dan konseling secara individual, kelompok, klasikal, kelas besar atau lintas kelas, dan atau menggunakan media. Layanan bimbingan dan konseling dapat dirancang secara khusus untuk dilaksanakan oleh guru bimbingan dan konseling atau konselor serta dapat pula dirancang berkolaborasi dengan staf lainnya (Kementrian Pendidikan dan Kebudayaan, 2016)

Dengan demikian untuk mengetahui karakteristik dan permasalahan yang dialami peserta didik, maka guru bimbingan konseling sebelum melaksanakan program bimbingan konseling alngkah baiknya memberikan kesempatan kepada peserta didik mengisi Angket kebutuhan Peserta Didik (AKPD), dimana AKPD merupakan sebuah angket yang berisi sejumlah soal berupa pernyataan terkait dengan masalah-masalah yang diasumsikan biasa terjadi pada peserta didik. Hasil pengolahan angket tersebut membnatu guru bimbingan dan konseling merancang program bimbingan konseling untuk mambantu peserta didik mengatasi permasalahan yang dialaminya (Transisilawati et al., 2019)

Dengan kata lain analisis kebutuhan peserta didik merupakan langkah awal untuk membantu guru bimbingan dan konseling merencanakan program dan melaksanakan program bimbingan dan konseling bagi peserta didik baik itu layanan konseling individual, konseling kelompok, bimbingan kelompok maupun bimbingan klasikal.

\section{Method}

Jenis penelitian ini adalah penelitian kuantitatif, dengan menggunakan pendekatan deskriptif yang bertujuan untuk mendeskripsikan secara sistematis, faktual dan akurat mengenai fakta-fakta dan populasi tertentu atau mencoba menggambarkan fenomena secara detail apa adanya (Yusup Muri A, 2005). Penelitian ini difokuskan pada pelaksanaan asesmen kebutuhan peserta didik dalam melaksanakan bimbingan klasikal Populasi penelitian ini adalah siswa kelas X SMA Laboratorium Universitas Pattimura Ambon Tahun Ajaran 2021/2022 berjumlah 4 orang. Teknik analisis data menggunakan teknik presentasi dan metode pengambilan sampel menggunakan sampling jenuh. Menurut Sugiyono jika populasinya kecil maka semua orang dijadikan sampel, dimana teknik penentuan sampel bila semua anggota populasi digunakan maka menggunakan teknik sampling jenuh.(Mahaly Sawal, 2021)

\section{Hasil dan Pembahasan}

Berdasarkan hasil pengolahan data kebutuhan peserta didik kelas X SMA Laboratorium Universitas Pattimura menggambarkan bahwa dari 51 aspek kebutuhan peserta didik yang paling dominan adalah 9 aspek antara lain peserta didik belum mengenal lingkungan sekolah baru, memperoleh bantuan pendidikan (beasiswa), perubahan dan permasalahan masa remaja, jarang bermain/berteman dengan lingkungan sekitar, gaya belajar dan strategi, cara belajar yang baik, ciri-ciri pribadi berkarakter, menjaga kesehatan diri serta memilih kegiatan eskstrakurikuler. Sedangkan yang aspek yang paling tertinggi ada 4 aspek antara lain mengenal lingkungan sekolah baru, memperoleh bantuan pendidikan (beasiswa), perubahan dan permasalahan masa remaja, jarang bermain/berteman dengan lingkungan sekitar. 
Hasil ini sangat membantu guru bimbingan dan konseling untuk mengetahui kebutuhan peserta didik untuk mendapatkan layanan bimbingan dan konseling baik itu layanan bimbingan konseling yang diberikan secara individu, kelompok maupun bimbingan klasikal. Dari layanan bimbingan konseling yang diberikanan agar dapat membantu peserta didik untuk mendapatkan pengetahuai terkait dengan pokok bahasan yang diberikan oleh guru bimbingan dan konseling. hasil kebutuhan peserta didik dapat dilihat pada tabel berikut:

Tabel.1

Kebutuhan Peserta Didik

\begin{tabular}{|c|c|c|c|}
\hline NO & KEBUTUHAN PESERTA DIDIK & $\begin{array}{c}\text { JUMLAH } \\
\text { RESPONDEN }\end{array}$ & PRESENTASE \\
\hline 1 & Belum banyak mengenal lingkungan sekolah baru & 4 & $100 \%$ \\
\hline 2 & Belum tahu cara memperoleh bantuan pendidikan (beasiswa) & 4 & $100 \%$ \\
\hline 3 & Belum tahu perubahan dan permasalahan yang terjadi pada masa remaja & 4 & $100 \%$ \\
\hline 4 & Jarang bermain/berteman di lingkungan tempat saya tinggal & 4 & $100 \%$ \\
\hline 5 & Belum paham tentang gaya belajar dan strategi yang sesuai dengannya & 3 & $75 \%$ \\
\hline 6 & Belum tahu cara belajar yang baik dan benar di SMA & 3 & $75 \%$ \\
\hline 7 & Belum tahu ciri-ciri/sifat/prilaku pribadi yang berkarakter & 3 & $75 \%$ \\
\hline 8 & Kurang menjaga kesehatan diri & 3 & $75 \%$ \\
\hline 9 & Merasa bingung memilih kegiatan esktrakurikuler di sekolah & 3 & $75 \%$ \\
\hline
\end{tabular}

Pada tabel kebutuhan peserta didik dapat digambarkan bahwa peserta didik sangat membutuhan bantuan dari guru bimbingan konseling untuk dapat memberikan pemahaman kepada peserta didik terkait dengan mengenal lingkungan sekolah baru, memperoleh bantuan pendidikan (beasiswa), perubahan dan permasalahan masa remaja, jarang bermain/berteman dengan lingkungan sekitar, gaya belajar dan strategi, cara belajar yang baik, ciri-ciri pribadi berkarakter, menjaga kesehatan diri serta memilih kegiatan eskstrakurikuler. Hasil ini memberikan informasi dan bantuan bagi guru bimbingan konseling dalam memberikan layanan bimbingan konseling bagi peserta didik di sekolah terkait dengan pemberian layanan bimbingan klasikal.

Bimbingan klasikal disebut layanan dasar karena bimbingan klasikal merupakan bagian yang memiliki porsi terbesar dalam layanan bimbingan dak konsleing di sekolah. Bimbingan klasikal lebih persifat preventif dan berorientasi pada pengembangan pribadi peserta didik yang melifut8 bidang belajar, sosial dan karir. Pemberian layanan bimbingan klasikal berfokus pada pencegahan dan peguasaan siswa akan tugas perkembangannya. Senada dengan hal tersebut Supriyo menambahkan agar dapat memberikan layanan secara tepat, maka perlu kiranya dilakukan analisis kebutuhan peserta didik. Layanan bimbingan klasikal dilakukan melalui tatap muka langsung dengan peserta didik untuk memberikan informasi-informasi yang bermanfaat dalam membantu peserta didik yang bermasalah (Shalima Meynar $\mathrm{P} \square$, 2013)

\section{Kesimpulan}

Peserta didik belum mengenal lingkungan sekolah baru, memperoleh bantuan pendidikan (beasiswa), perubahan dan permasalahan masa remaja, jarang bermain/berteman dengan lingkungan sekitar, gaya belajar dan strategi, cara belajar yang baik, ciri-ciri pribadi berkarakter, menjaga kesehatan diri serta memilih kegiatan eskstrakurikuler. Beradsarkan hasil temuan diatas, maka aspek yang paling utama diberikan oleh guru bimbingan konseling dalam pemberian layanan bimbingan klasikal antara lain mengenal lingkungan sekolah baru, memperoleh bantuan pendidikan (beasiswa), memahami perubahan dan permasalahan masa remaja, dan bermain/berteman dengan lingkungan sekitar.

\section{Acknowledgments}

Penulis mengucapkan banyak terimakasih kepada BPS (Badan Penyelenggara Sekolah) Universitas Pattimura SMA Laboratorium Universtias Pattimura yang memberikan izin untuk melaksanakan penelitian tentang kebutuhan peserta didik disekolah. Hasil ini membantu kami sebagai guru bimbingan konseling dalam melaksanakan layanan bimbingan klasikal bagi peserta didik.

\section{References}

Divinubun, S., Mahaly, S., Rekreasi, K., Keguruan, F., Pattimura, U., Keguruan, F., Pattimura, U., Islam, B. K., Dakawah, U., \& Ambon, I. (2021). Pelatihan Penggunaan DCM (Daftar Cek Masalah) Bagi Guru Bimbingan Konseling Dalam Mengidentifikasi Masalah Siswa. 1(1), 19-23.

Kementrian Pendidikan dan Kebudayaan. (2016). Panduan Operasional Penyelenggaraan Bimbingan Dan Konseling Sekolah Menengah Atas (SMA). Ditjen Guru Dan Tenaga Kependidikan Kemendikbud, 1-144. 
Mahaly, S. (2021). Efektivitas Pelaksanaan Layanan Bimbingan Pribadi Oleh Guru Bimbingan Konseling. AlIttizaan: Jurnal Bimbingan Konseling Islam, 4(1), 1-5. https://doi.org/10.24014/ittizaan.v4i1.13238

Mahaly Sawal, R. E. (2021). Cooperation Between Counselingcourses Teacher And Teacher in Hekping Students' Learning Activities. International Journa L of Education, Information Technology and Others (Ijeit), 4(2), 467-473. https://doi.org/10.5281/zenodo.5221556

Permadin, L. P. (2021). Asesmen kebutuhan konseli dalam perencanaan program bimbingan dan konseling di sekolah menengah pertama 1 meiga latifah putri permadin \& 2. 111, 27-33.

Rahmad, M., Husen, M., \& Fajriani, F. (2019). Analisis Kebutuhan Siswa Dalam Penyusunan Program Layanan Bimbingan Dan Konseling. Jurnal Ilmiah Mahasiswa Bimbingan Dan Konselin, 4(2), 88-98.

Shalima Meynar P $\square$, K. K. (2013). PERSEPSI SISWA KELAS XI TERHADAP LAYANAN BIMBINGAN KLASIKAL DI SMAN 7 SEMARANG. Indonesian Journal of Guidance and Counseling : Theory and Application, 4(2), 70-71.

Tohirin. (2011). Bimbingan dan Konseling di Sekolah dan Madrasah (berbasis integrasi). Rajawali Pres.

Transisilawati, U., Rosely, E., \& Wisnu Wijayanto, P. (2019). Aplikasi Pengidentifikasian Permasalahan Siswa Berbasis Web (Studi Kasus: Smpn 21 Bandung). 5(3), 2182-2188.

Yusup Muri A. (2005). Metodologi Penelitian. UNP Pres. 